Journal Economics and Management (JECMA)

Volume 1, No. 02, Februari 2021, p. 42-49

\title{
Pengaruh Work Engagement Terhadap Kinerja Pegawai BPJS Ketenagakerjaan
}

\author{
Effect of Work Engagement on Employee Performance of BPJS Ketenagakerjaan
}

\author{
Asipola Rohana Manalu*1, Rinandar Thamrin², Muridha Hasan ${ }^{3}$, Deny Syahputra ${ }^{4}$ \\ ${ }^{1,2,3,4}$ Program Studi Magister Manajemen, Fakultas Ekonomi, Universitas Islam Sumatera Utara, \\ Indonesia \\ e-mail correspondence author: *aispolarohanamanalu11@gmail.com
}

\begin{abstract}
ABSTRAK
Dalam menjalankan kegiatan operasionalnya, organisasi pasti memiliki beberapa faktor yang terikat dan berpengaruh satu sama lain dan salah satunya adalah sumber daya manusia yang dimililkinya. Penelitian akan meneliti mengenai pengaruh work engagement terhadap kinerja pegawai di BPJS Ketenagakerjaan Cabang Binjai. Pendekatan yang digunakan adalah metode kuantitatif. Lokasi penelitian dilakukan di BPJS Ketenagakerjaan Cabang Binjai. Objek penelitian ini adalah work engagement sebagai variabel X dan kinerja pegawai sebagai variabel Y. Dari hasil penelitian didapatkan bahwa work engagement $(X)$ berpengaruh lebih dominan terhadap kinerja pegawai BPJS Ketenagakerjaan Cabang Binjai. Selain itu Work Engagement berpengaruh positif dan signifikan terhadap kinerja pegawai di BPJS Ketenagakerjaan Cabang Binjai dengan $t_{\text {hitung }}>t_{\text {tabel }}(2.759>2.030)$ dan nilai koefisien regresi sebesar 0.389 atau $38,9 \%$. Kata kunci: kinerja pegawai, work engagement, organisasi
\end{abstract}

\begin{abstract}
In carrying out activities to achieve its goals, an organization has several factors that are interrelated and influential. One of them is human resources. This research will examine the effect of work engagement on employee performance at BPJS Ketenagakerjaan Binjai Branch. The approach used is a quantitative method. The research location was conducted at the Binjai Branch of the BPJS Ketenagakerjaan. The object of this research is work engagement as variable $X$ and employee performance as variable Y. From the research, it is found that work engagement $(X)$ has a more dominant effect on the performance of employees of the Binjai Branch of BPJS Ketenagakerjaan. In addition, Work Engagement has a positive and significant effect on employee performance at BPJS Ketenagakerjaan Binjai Branch with tcount> ttable (2.759> 2.030) and a regression coefficient value of 0.389 or $38.9 \%$
\end{abstract}

Keywords: employee performance, work engagement, organization.

\section{INTRODUCTION}

Suatu organisasi memiliki beberapa faktor yang saling terkait dan berpengaruh dalam menjalankan aktivitas untuk mencapai tujuannya. Salah satu faktor penting tersebut adalah sumber daya manusia yang dapat mengoptimalkan kegiatan organisasi. Oleh karena itu, pengelolaan sumber daya manusia dirasakan sangat penting dalam suatu perusahaan selain modal. Karena pengelolaan sumber daya manusia adalah untuk mendapatkan karyawan-karyawan yang handal dan mampu melaksanakan tugasnya secara benar dan bertanggung jawab, maka hal ini dapat meningkatkan efektifitas dan efisiensi organisasi dalam mencapai tujuannya secara cepat.

Didalam pengelolaan SDM, apabila individu dalam organisasi yaitu sumber daya manusianya dapat berjalan efektif maka organisasi tetap berjalan efektif. Beberapa kegiatan pengelolaan SDM misalnya pengadaan, penilaian, perlindungan, memotivasi karyawan, memberdayakan pegawai, peningkatan disiplin, bimbingan, dll. Pengelolaan dan pengoptimalan sumber daya manusia tidak lepas dari faktor karyawan. Organisasi harus mempunyai karyawankaryawan mempunyai kinerja yang baik. Dengan kata lain kelangsungan suatu organisasi ditentukan oleh kinerja karyawannya.

Engagement merupakan konsep kompleks yang dipengaruhi oleh banyak faktor, seperti budaya di tempat kerja, komunikasi organisasional, gaya manajerial yang memicu kepercayaan

Submitted: Januari 2021, Accepted: Februari 2021, Published: Februari 2021

ISSN: 2746-0568 (online), Website: http://jurnal.umus.ac.id/index.php/jecma 
Journal Economics and Management (JECMA), Volume 1, No. 02, Februari 2021, p. 42-49

dan penghargaan serta kepemimpinan yang dianut dan reputasi perusahan itu sendiri[1]. Engagement juga dipengaruhi karakteristik organisasional, seperti reputasi untuk integritas, komunikasi internal yang baik, dan inovasi budaya[2]. Ketika suatu karyawan telah memiliki ketertarikan terhadap pekerjaan yang diberikan maka hal tersebut dapat menjadi faktor penentu dalam kesuksesan. Work engagement dalam pekerjaan dikonsepsikan sebagai anggota organisasi yang melaksanakan peran kerjanya, bekerja dan mengekspresikan dirinya secara fisik, kognitif dan emosional selama bekerja[3]. Selain itu dalam menciptakan predictor utama berdasarkan work engagement maka diperlukan Job Resources dan Personal Resource [4].

Karyawan yang terikat akan bekerja dengan keras dengan pikiran yang positif, maka dari itu mereka lebih cepat atau banyak menyelesaikan hal-hal di tempat kerja[5]. Ketika karyawan terikat, secara otomatis mereka akan meningkatkan kinerjanya selaras dengan goal yang ingin dicapai oleh perusahaan. Karyawan yang memiliki engagement dapat dilihat dengan tidak merasakan pekerjaan sepenuhnya tentang deskripsi pekerjaan yang dilakukan namun karyawan mampu fokus pada tujuan dan mencoba untuk mencapai secara konsisten akan suksesnya suatu perusahaan. Karyawan secara aktif mencari jalan untuk dapat memperluas kemampuan yang dimiliki serta karyawan pantang menyerah walau dihadapkan dengan situasi yang menyulitkan. Permasalahan yang ada saat ini adalah rendahnya keterikatan pegawai, adanya pegawai yang terlihat kurang bersemangat dan antusias ketika melakukan pekerjaannya sehingga menyebabkan pekerjaan memakan waktu lebih lama atau dalam kata lain tidak efisien. Jika permasalahan yang terjadi seperti ini tidak dikelola dan disikapi dengan baik, maka perusahaan akan kesulitan untuk berkembang.

\section{LITERATURE REVIEW}

Work engagement merupakan suatu pola pikir positif pegawai terhadap pekerjaan berdasarkan semangat, dedikasi dan fokus terhadap pekerjaan yang diberikan ditempat kerja[6]. Seorang karyawan dapat dikatakan work engagement ketika seorang karyawan sudah mampu menjadikan pekerjaannya sebagai prioritas untuk diri dan pribadinya selain untuk organisasi. Selain itu peneliti mendefinisikan work engagement sifat pribadi karyawan yang bangga telah menjadi bagian dari suatu organisasi sehingga mampu bekerja sesuai dengan jobdesk yang diberikan[7].

Kinerja pegawai adalah suatu hal yang dilakukan dan tidak dilakukan oleh pegawai dalam hal kualitas, kuantitas, ketepatan, kehadiran dan kemampuan pegawai dalam bekerja sama[8]. Peneliti [9] mendefinisikan bahwa kinerja pegawai memiliki hubungan erat dengan kinerja organisasi dimana penilaian seorang pegawai dapat dilihat berdasarkan hasil kerja sesuai dengan tugas dan tanggungjawab yang diberikan untuk mendukung tujuan organisasi tersebut. Peneliti [10] berpendapat bahwa kinerja pegawai merupakan suatu prestasi individu terhadap pencapaian kerja yang telah dilakukan dalam melaksanakan pekerjaan yang diberikan kepadanya. Kinerja pegawai juga berpengaruh terhadap kompetensi, motivasi dan kepuasan kerja, dimana ternyata motivasi memiliki pengaruh yang positif dan signifikan terhadap kinerja suatu pegawai[11].

\section{METHODS}

Pendekatan yang digunakan dalam penelitian ini adalah metode kuantitatif, dimana penelitian yang dilakukan berdasarkan perkataan lisan dan pengamatan perilaku terhadap subyek dan obyek yang akan diteliti[12]. Penelitian ini menggunakan kuantitatif dengan cara Analisa terhadap dokumen, analisis taksonomi, dan analisis kompensional.

Lokasi penelitian dilakukan di BPJS Ketenagakerjaan Cabang Binjai, berlamat di Jl. Soekarno-Hatta No. 262, Km.19,5 Tunggurono, Kec. Binjai Timur, Kota Binjai, Sumatera Utara 20351. Objek penelitian ini adalah work engagement sebagai variabel $X$ dan kinerja pegawai sebagai variabel Y. 
Journal Economics and Management (JECMA), Volume 1, No. 02, Februari 2021, p. 42-49

\section{RESULTS AND DISCUSSION}

Kuesioner yang disebar ke responden atau pegawai BPJS Ketenagakerjaan Cabang Binjai berjumlah 35 orang. Berikut peneliti akan mendeskripsikan identitas responden berdasarkan jenis kelamin dan unit kerja responden.

Tabel 1. Identitas Responden Berdasarkan Jenis Kelamin

\begin{tabular}{cccc}
\hline No & Jenis Kelamin & Jumlah & Persentase (\%) \\
\hline 1 & Laki-laki & 18 & $51,4 \%$ \\
\hline 2 & Perempuan & 17 & $48,6 \%$ \\
\hline & Total & $\mathbf{3 5}$ & $\mathbf{1 0 0 \%}$ \\
\hline
\end{tabular}

Sumber: BPJS Ketenagakerjaan Cabang Binjai 2020

Berdasarkan Tabel 1, dapat diketahui bahwa responden laki-laki adalah 18 orang atau setara dengan 51,4\% dan responden perempuan adalah 17 orang atau sama dengan 48,6\%. Dari Tabel 1, penulis spesifikasian menjadi beberapa unit kerja, dimana terdapat 8unit kerja yang semuanya terangkum pada Table 2 .

Tabel 2. Identitas Responden Berdasarkan Unit Kerja

\begin{tabular}{clcc}
\hline No & Bagian/Unit Kerja & Jumlah & Persentase \\
\hline 1 & Bagian Kepesertaan & 9 & $26 \%$ \\
\hline 2 & Bagian Pelayanan & 5 & $14 \%$ \\
\hline 3 & Bagian Keuangan & 3 & $9 \%$ \\
\hline 4 & Bagian Umum dan SDM & 5 & $14 \%$ \\
\hline 5 & KCP & 4 & $11 \%$ \\
\hline 6 & Bagian Pengawasan & 3 & $9 \%$ \\
\hline 7 & Bagian Teknologi Informatika & 2 & $6 \%$ \\
\hline 8 & Office Support & 4 & $11 \%$ \\
\hline & & $\mathbf{3 5}$ & $\mathbf{1 0 0 \%}$ \\
\hline
\end{tabular}

Sumber: BPJS Ketenagakerjaan Cabang Binjai 2020

\section{Pernyataan Responden Atas Work Engagement $\left(\mathbf{X}_{1}\right)$}

Penjelasan responden atas indikator-indikator variabel work engagement di BPJS Ketenagakerjaan Cabang Binjai terangkum pada Tabel 3

Tabel 3. Penjelasan Responden Atas Variabel Work Engagement (X)

\begin{tabular}{|c|c|c|c|c|c|c|c|c|c|c|c|c|}
\hline \multirow{3}{*}{ No } & \multicolumn{12}{|c|}{ ALTERNATIF JAWABAN } \\
\hline & \multicolumn{2}{|c|}{ SS } & \multicolumn{2}{|r|}{$\mathbf{S}$} & \multicolumn{2}{|c|}{ KS } & \multicolumn{2}{|c|}{ TS } & \multicolumn{2}{|c|}{ STS } & \multicolumn{2}{|c|}{ Jumlah } \\
\hline & $\mathbf{F}$ & $\%$ & $\mathbf{F}$ & $\%$ & $\mathbf{F}$ & $\%$ & $\mathbf{F}$ & $\%$ & $\mathbf{F}$ & $\%$ & $\mathbf{F}$ & $\%$ \\
\hline 1 & 17 & $48,6 \%$ & 14 & $40,0 \%$ & 4 & $11,4 \%$ & 0 & $0,0 \%$ & 0 & $0,0 \%$ & 35 & $100,0 \%$ \\
\hline 2 & 14 & $40,0 \%$ & 16 & $45,7 \%$ & 5 & $14,3 \%$ & 0 & $0,0 \%$ & 0 & $0,0 \%$ & 35 & $100,0 \%$ \\
\hline 3 & 9 & $25,7 \%$ & 15 & $42,9 \%$ & 7 & $20,0 \%$ & 3 & $8,6 \%$ & 1 & $2,9 \%$ & 35 & $100,0 \%$ \\
\hline 4 & 6 & $17,1 \%$ & 25 & $71,4 \%$ & 4 & $11,4 \%$ & 0 & $0,0 \%$ & 0 & $0,0 \%$ & 35 & $100,0 \%$ \\
\hline 5 & 15 & $42,9 \%$ & 13 & $37,1 \%$ & 6 & $17,1 \%$ & 1 & $2,9 \%$ & 0 & $0,0 \%$ & 35 & $100,0 \%$ \\
\hline 6 & 15 & $42,9 \%$ & 16 & $45,7 \%$ & 4 & $11,4 \%$ & 0 & $0,0 \%$ & 0 & $0,0 \%$ & 35 & $100,0 \%$ \\
\hline
\end{tabular}


Journal Economics and Management (JECMA), Volume 1, No. 02, Februari 2021, p. 42-49

\begin{tabular}{|c|c|c|c|c|c|c|c|c|c|c|c|c|}
\hline Rata-rata & 13 & $36,2 \%$ & 17 & $47,1 \%$ & 5 & $14,3 \%$ & 1 & $1,9 \%$ & 0 & $0,5 \%$ & 35 & $100,0 \%$ \\
\hline
\end{tabular}

Dari Tabel 3 dapat dijelaskan bahwa:

1) Jawaban responden pertanyaan No.1: Saya selalu tekun bekerja, meskipun ada hal yang tidak sesuai dengan harapan saya. Responden yang menjawab sangat setuju sebesar 48,6\%, setuju sebesar $40,0 \%$, kurang setuju sebesar $11,4 \%$.

2) Jawaban responden pertanyaan No. 2: Saya dapat bekerja dalam waktu yang lama pada satu periode pekerjaan. Responden yang menjawab sangat setuju 40,0\%, setuju sebesar $45,7 \%$ dan kurang setuju sebesar $14,3 \%$.

3) Jawaban responden pertanyaan No. 3: Saya selalu merasa senang berangkat bekerja. Responden yang menjawab sangat setuju sebesar $25,7 \%$, setuju sebesar $42,9 \%$, dan kurang setuju sebesar $20,0 \%$, tidak setuju sebesar $8,6 \%$.

4) Jawaban responden pertanyaan No. 4: Berkaitan dengan pekerjaan, Saya telah menemukan satu pekerjaan yang sangat bermakna dan penuh harapan. Responden yang menjawab sangat setuju sebesar $17,1 \%$, yang menjawab setuju sebesar $71,4 \%$ dan yang menjawab kurang setuju sebesar $11,4 \%$.

5) Jawaban responden pertanyaan No. 5: Pada saat sedang bekerja, Saya bisa lupa dengan sekeliling saya. Responden yang menjawab sangat setuju sebesar $42,9 \%$, responden yang menjawab setuju sebesar $37,1 \%$ dan yang menjawab kurang setuju sebesar $17,1 \%$, tidak setuju sebesar $2,9 \%$.

6) Jawaban responden pertanyaan No. 6: Waktu berjalan tak terasa ketika saya sedang bekerja. Responden yang menjawab sangat setuju sebesar $42,9 \%$, responden yang menjawab setuju sebesar $45,7 \%$ dan yang menjawab kurang setuju sebesar $11,4 \%$.

Secara rata-rata dapat dilihat bahwa yang terbesar jawaban responden adalah $47,1 \%$ menyatakan setuju. Dengan demikian dapat diketahui bahwa work engagement di BPJS Ketenagakerjaan Cabang Binjai adalah baik, sesuai dengan jawaban sebagian besar responden.

\section{Pernyataan Responden Atas Kinerja pegawai (Y)}

Penjelasan responden atas indikator-indikator variabel kinerja pegawai (Y) di BPJS Ketenagakerjaan Cabang Binjai, disajikan pada Tabel 4

Tabel 4. Penjelasan Responden Atas Variabel Kinerja (Y)

\begin{tabular}{|c|c|c|c|c|c|c|c|c|c|c|c|c|}
\hline \multirow{3}{*}{ No } & \multicolumn{12}{|c|}{ ALTERNATIF JAWABAN } \\
\hline & \multicolumn{2}{|c|}{ SS } & \multicolumn{2}{|c|}{$\mathbf{S}$} & \multicolumn{2}{|c|}{ KS } & \multicolumn{2}{|c|}{ TS } & \multicolumn{2}{|c|}{ STS } & \multicolumn{2}{|c|}{ Jumlah } \\
\hline & $\mathbf{F}$ & $\%$ & $\mathbf{F}$ & $\%$ & $\mathbf{F}$ & $\%$ & $\mathbf{F}$ & $\%$ & $\mathbf{F}$ & $\%$ & $\mathbf{F}$ & $\%$ \\
\hline 1 & 18 & $51,4 \%$ & 17 & $48,6 \%$ & 0 & $0,0 \%$ & 0 & $0,0 \%$ & 0 & $0,0 \%$ & 35 & $100,0 \%$ \\
\hline 2 & 9 & $25,7 \%$ & 25 & $71,4 \%$ & 1 & $2,9 \%$ & 0 & $0,0 \%$ & 0 & $0,0 \%$ & 35 & $100,0 \%$ \\
\hline 3 & 7 & $20,0 \%$ & 17 & $48,6 \%$ & 11 & $31,4 \%$ & 0 & $0,0 \%$ & 0 & $0,0 \%$ & 35 & $100,0 \%$ \\
\hline 4 & 14 & $40,0 \%$ & 14 & $40,0 \%$ & 7 & $20,0 \%$ & 0 & $0,0 \%$ & 0 & $0,0 \%$ & 35 & $100,0 \%$ \\
\hline 5 & 7 & $20,0 \%$ & 23 & $65,7 \%$ & 5 & $14,3 \%$ & 0 & $0,0 \%$ & 0 & $0,0 \%$ & 35 & $100,0 \%$ \\
\hline 6 & 8 & $22,9 \%$ & 17 & $48,6 \%$ & 10 & $28,6 \%$ & 0 & $0,0 \%$ & 0 & $0,0 \%$ & 35 & $100,0 \%$ \\
\hline Rata-rata & 11 & $30,0 \%$ & 19 & $53,8 \%$ & 6 & $16,2 \%$ & 0 & $0,0 \%$ & 0 & $0,0 \%$ & 35 & $100,0 \%$ \\
\hline
\end{tabular}

Sumber: Hasil Penelitian 2020

Dari Tabel 4 dapat dijelaskan bahwa: 
Journal Economics and Management (JECMA), Volume 1, No. 02, Februari 2021, p. 42-49

1) Jawaban responden pertanyaan No.1: Kuantitas hasil kerja pegawai selama ini dapat dikategorikan baik. Responden yang menjawab sangat setuju sebesar $51,4 \%$, responden yang menjawab setuju sebesar $48,6 \%$.

2) Jawaban responden pertanyaan No. 2: Kualitas hasil kerja pegawai selama ini dapat dikategorikan baik. Responden yang menjawab sangat setuju sebesar $25,7 \%$, responden yang menjawab setuju sebesar $71,4 \%$, responden yang menjawab kurang setuju sebesar $2,9 \%$.

3) Jawaban responden pertanyaan No. 3: Tingkat efisiensi kerja para pegawai dapat dikategorikan baik. Responden yang menjawab sangat setuju sebesar 20,0\%, responden yang menjawab setuju sebesar $48,6 \%$, responden yang menjawab kurang setuju sebesar $31,4 \%$.

4) Jawaban responden pertanyaan No. 4: Proses pelayanan, administrasi dan informasi pegawai terhadap yang membutuhkan sudah baik. Responden yang menjawab sangat setuju sebesar 40,0\%, responden yang menjawab setuju sebesar 40,0\%, responden yang menjawab kurang setuju sebesar $20,0 \%$.

5) Jawaban responden pertanyaan No. 5: Ketepatan pegawai dalam melaksanakan suatu pekerjaan sudah baik. Responden yang menjawab sangat setuju sebesar 20,0\%, responden yang menjawab setuju sebesar $65,7 \%$, responden yang menjawab kurang setuju sebesar $14,3 \%$.

6) Jawaban responden pertanyaan No. 6: Pengetahuan pegawai berkaitan dengan pekerjaan utamanya sudah baik. Responden yang menjawab sangat setuju sebesar $22,9 \%$, responden yang menjawab setuju sebesar $48,6 \%$, kurang setuju sebesar $28,6 \%$

Secara rata-rata dapat dilihat bahwa yang terbesar jawaban responden adalah 53,8\% menyatakan setuju. Dengan demikian dapat diketahui bahwa kinerja pegawai di BPJS Ketenagakerjaan Cabang Binjai adalah baik, sesuai dengan jawaban sebagian besar responden

\section{Uji Validitas}

Uji validitas digunakan untuk mengetahui nilai skor butir pernyataan dan total skor dari pertanyaan-pertanyaan yang diberikan[13]. Dari tabel 5 dan 6 terlihat bahwa kolerasi semua item untuk work engagement $(\mathrm{X})$, menunjukan hasil yang signifikan yaitu nilai pearson correlation > 0.333 sehingga dapat disimpulkan semua butir pernyataan work engagement $\left(\mathrm{X}_{1}\right)$ adalah valid.

Tabel 5. Uji Validitas Instrumen Work Engagement $(\mathbf{X})$

\begin{tabular}{cccc}
\hline $\begin{array}{c}\text { No. } \\
\text { Item }\end{array}$ & $\begin{array}{c}\text { Corrected item- } \\
\text { total correlation } \\
(\mathbf{~ r h i t u n g ) ~}\end{array}$ & $(\mathbf{n}=\mathbf{3 5}, \boldsymbol{\alpha}=\mathbf{5 \%})$ & Kesimpulan \\
\hline $\mathrm{Q} 11$ & 0.732 & 0.333 & Valid \\
\hline $\mathrm{Q} 12$ & 0.867 & 0.333 & Valid \\
\hline $\mathrm{Q} 13$ & 0.602 & 0.333 & Valid \\
\hline $\mathrm{Q} 14$ & 0.841 & 0.333 & Valid \\
\hline $\mathrm{Q} 15$ & 0.821 & 0.333 & Valid \\
\hline $\mathrm{Q} 16$ & 0.848 & 0.333 & Valid \\
\hline
\end{tabular}

Sumber: Hasil Pengolahan SPSS 2020

Tabel 6. Uji Validitas Instrumen Kinerja Pegawai (Y) 
Journal Economics and Management (JECMA), Volume 1, No. 02, Februari 2021, p. 42-49

$\begin{array}{cccc}\begin{array}{c}\text { No. } \\ \text { Item }\end{array} & \begin{array}{c}\text { Corrected item- } \\ \text { total correlation } \\ \left(\mathbf{r}_{\text {hitung })}\right)\end{array} & \begin{array}{c}\left(\mathbf{r}_{\text {tabel) }}\right) \\ (\mathbf{n}=\mathbf{3 5}, \boldsymbol{\alpha}=\mathbf{5 \%})\end{array} & \text { Kesimpulan } \\ \text { Q41 } & 0.631 & 0.333 & \text { Valid } \\ \text { Q42 } & 0.547 & 0.333 & \text { Valid } \\ \text { Q43 } & 0.847 & 0.333 & \text { Valid } \\ \text { Q44 } & 0.626 & 0.333 & \text { Valid } \\ \text { Q45 } & 0.658 & 0.333 & \text { Valid } \\ \text { Q46 } & 0.844 & 0.333 & \text { Valid }\end{array}$

Sumber: Hasil Pengolahan SPSS 2020

\section{Uji Reliabilitas}

Untuk menguji reliabilitas yang paling sering digunakan kebanyakan peneliti dengan menggunakan Crobach Alpha. Nilai suatu kuesioner dinyatakan reliabel biasanya ditetapkan dengan angka alpha 0.70-0.80 cukup baik untuk tujuan penelitian dasar menurut Kaplan-Saccuzz (2013:12) atau dapat dengan menggunakan tabel 7.

Tabel 7. Interprestasi Nilai Reliabilitas Instrument Interprestasi.

\begin{tabular}{cc}
\hline $\begin{array}{c}\text { Interprestasi Nilai Reliabilitas } \\
\text { Instrument }\end{array}$ & Interprestasi \\
\hline $0,80-1,00$ & Tinggi \\
\hline $0,60-0,80$ & Cukup \\
\hline $0,40-0,60$ & Agak rendah \\
\hline $0,20-0,40$ & Rendah \\
\hline $0,00-0,20$ & Sangat rendah \\
\hline
\end{tabular}

Sumber: Kaplan-Saccuzz, (2013:12)

Tabel 7. Uji Reliabilitas X dan Y

\begin{tabular}{lccc}
\hline \multicolumn{1}{c}{ Variabel } & $\begin{array}{c}\text { Nilai } \\
\text { Alpha }\end{array}$ & $\begin{array}{c}\text { Reliabel/Tidak } \\
\text { Reliabel }\end{array}$ & Keterangan \\
\hline $\begin{array}{l}\text { Work Engagement } \\
\left(\mathrm{X}_{1}\right)\end{array}$ & 0.849 & Reliabel (Tinggi) & Dipakai \\
\hline Kinerja Pegawai (Y) & 0.786 & Reliabel (Cukup) & Dipakai \\
\hline Sumber: Hasil Pengolahan SPSS 2020 & &
\end{tabular}

Tabel 8. Hasil Uji Parsial

\begin{tabular}{|c|c|c|c|c|c|c|}
\hline \multicolumn{7}{|c|}{ Coefficients $^{a}$} \\
\hline & \multirow[t]{2}{*}{ Model } & \multicolumn{2}{|c|}{$\begin{array}{l}\text { Unstandardized } \\
\text { Coefficients }\end{array}$} & \multirow{2}{*}{$\begin{array}{c}\begin{array}{c}\text { Standardized } \\
\text { Coefficients }\end{array} \\
\text { Beta }\end{array}$} & \multirow[t]{2}{*}{$\mathbf{T}$} & \multirow[t]{2}{*}{ Sig. } \\
\hline & & B & Std. Error & & & \\
\hline \multirow{2}{*}{1} & (Constant) & 11.875 & 3.060 & & 3.881 & .001 \\
\hline & Work_Engagement & .320 & .116 & .389 & 2.759 & .010 \\
\hline
\end{tabular}

Sumber: Hasil Pengolahan SPSS 2020

Dari Tabel 8 diperoleh nilai thitung masing-masing variabel. Nilai thitung tersebut selanjutnya dibandingkan dengan nilai tabel pada tingkat kepercayaan $95 \%$ atau $\alpha=0,05$. Nilai tabel pada $\mathrm{df}$ 3:35 dengan $\alpha=0,05$ adalah 2.030. Pengaruh parsial dari variabel work engagement $\left(\mathrm{X}_{1}\right)$ diperoleh dengan nilai $t_{\text {hitung }}$ sebesar 2.759 , dengan demikian $t_{\text {hitung }}>t_{\text {tabel }}(2.759>2.030)$ dengan nilai signifikan sebesar $0.010<0.05$, maka $\mathrm{H}_{0}$ ditolak dan $\mathrm{H}_{1}$ diterima, yang berarti bahwa variabel work engagement $\left(\mathrm{x}_{1}\right)$ berpengaruh positif dan signifikan terhadap kinerja pegawai di BPJS Ketenagakerjaan Cabang Binjai. Hal ini berarti bahwa apabila work engagement $\left(\mathrm{X}_{1}\right)$ 
Journal Economics and Management (JECMA), Volume 1, No. 02, Februari 2021, p. 42-49

meningkat atau semakin baik maka kinerja pegawai di BPJS Ketenagakerjaan Cabang Binjai juga akan meningkat.

\section{CONCLUSION}

Berdasarkan hasil analisis diketahui bahwa nilai koefisien regresi yang paling tinggi adalah variabel work engagement (X) sebesar 0.389 atau 38,9\%. Hal ini berarti bahwa work engagement (X) berpengaruh lebih dominan terhadap kinerja pegawai BPJS Ketenagakerjaan Cabang Binjai. Work Engagement berpengaruh positif dan signifikan terhadap kinerja pegawai di BPJS Ketenagakerjaan Cabang Binjai dengan $t_{\text {hitung }}>t_{\text {tabel }}(2.759>2.030)$ dan nilai koefisien regresi sebesar 0.389 atau $38,9 \%$.

\section{REFERENCES}

[1] F. A. Aziz and S. Raharso, "Pengaruh Work Engagement Terhadap Employee Service Innovative Behavior : Kajian Empiris Di Minimarket," Pros. Ind. Res. Work. Natl. Semin., vol. 10, no. 1, 2019, doi: https://doi.org/10.35313/irwns.v10i1.1515.

[2] S. A. Prahara and S. Hidayat, "Budaya Organisasi dengan Work Engagement pada Karyawan," J. RAP (Riset Aktual Psikol. Univ. Negeri Padang), vol. 10, no. 2, p. 232, 2020, doi: 10.24036/rapun.v10i2.106977.

[3] D. Angelia and D. P. Astiti, "Gaya Kepemimpinan Transformasional : Tingkatkan Work Engagement," Psikobuletin Bul. Ilm. Psikol., vol. 1, no. 3, pp. 187-195, 2020, doi: http://dx.doi.org/10.24014/pib.v1i3.9940.

[4] N. Iksan and S. Widodo, "Pengaruh Sumber Daya Pekerjaan, Sumber Daya Individu Dan Beban Kerja Terhadap Keterikatan Kerja Dan Dampaknya Pada Kinerja Pegawai Sekretariat Daerah Kabupaten Seluma," J. Ilm. Ilmu Manaj. dan Bisnis, vol. 2, no. 2, 2020, doi: https://doi.org/10.33369/mr.2.2.52-67.

[5] M. R. Solichin, “Analisis Pengaruh Employee Engagement, Emotional Intelligence, dan Komitmen terhadap Organizational Citizenship Behavior ( OCB ) pada Karyawan PO Efisiensi Cabang Kebumen," J. Ekon. dan Tek. Inform. STIE Putra Bangsa, vol. 6, no. 2, pp. 36-47, 2018.

[6] R. Pri and Z. Zamralita, "Gambaran Work Engagement Pada Karyawan Di Pt Eg (Manufacturing Industry)," J. Muara Ilmu Sos. Humaniora, dan Seni, vol. 1, no. 2, p. 295, 2018, doi: 10.24912/jmishumsen.v1i2.981.

[7] D. Riyanto and I. Helmy, "Pengaruh Person Job Fit dan Job Crafting Terhadap Organizational Citizenship Behavior dengan Work Engagement sebagai Variabel Intervening," J. Ilm. Mhs. Manajemen, Bisnis dan Akunt., vol. 2, no. 3, pp. 426-433, 2020, doi: 10.32639/jimmba.v2i3.488.

[8] A. Hidayat, "Budaya Kerja, Kepuasan Kerja dan Kinerja Pegawai PT. Trijaya Medika Farma: Motivasi Sebagai Moderator," SAINS J. Manaj. dan Bisnis, vol. 10, no. 1, 2017, doi: http://dx.doi.org/10.35448/jmb.v10i1.4274.

[9] U. Oemar and L. Gangga, "Pengaruh Stres Kerja Terhadap Kinerja Pegawai Pada Dinas Pendapatan, Keuangan Dan Aset Daerah Kabupaten Musi Manyuasin," J. Ecoment Glob., vol. 2, no. 2, p. 22, 2017, doi: 10.35908/jeg.v2i2.249.

[10] Y. Ardiansyah and L. H. Sulistiyowati, "Pengaruh Kompetensi dan Kecerdasan Emosional Terhadap Kinerja Pegawai," J. Inspirasi Bisnis dan Manaj., vol. 2, no. 1, pp. 91-100, 2018.

[11] R. Rosmaini and H. Tanjung, "Pengaruh Kompetensi, Motivasi Dan Kepuasan Kerja Terhadap Kinerja Pegawai," Maneggio J. Ilm. Magister Manaj., vol. 2, no. 1, pp. 1-15, 2019, doi: 10.30596/maneggio.v2i1.3366.

[12] I. Afrita, A. Imron, and I. Arifin, "Manajemen Hubungan Sekolah Dengan Dunia Usaha Dan Industri Dalam Meningkatkan Prestasi Belajar Peserta Didik Sekolah Menengah Vokasional," J. Adm. dan Manaj. Pendidik., vol. 1, no. 3, pp. 313-319, 2018, doi: 
Journal Economics and Management (JECMA), Volume 1, No. 02, Februari 2021, p. $42-49$

10.17977/um027v1i32018p313.

[13] M. K. Maulana, "TERHADAP PRESTASI KERJA KARYAWAN PT . JELAJAH LAUT NUSANTARA JAKARTA,” J. Ekon. dan Ind., vol. 20, no. 1, 2019, doi: http://dx.doi.org/10.35137/jei.v20i1.244. 